Membership

APSA Offers Joint Membership

June 1995

Organized Sections

APSA Organized Section News

September 1994

Section News

Section News

Section News

Presidents and Officers

New APSA Officers Elected

December $1994 \quad 748$

March $1995 \quad 135$

June $1995 \quad 268$

APSA Treasurer's Report

December $1994 \quad 748$

Elinor Ostrom Nominated President-Elect

December $1994 \quad 756$

Profession

AAUP and CAUT Censure List

Placement Report: New Political Scientists on the Job

June 1995

September $1994 \quad 653$ Market in 1994

Professional Development

1995 Annual Meeting Short Courses

June 1995

PS Reports

Index of APSA Reports

Listing of Area Studies Organizations

Listing of Organizations Related to the Study of

Political Science

PS Index of Authored Articles

Publications

Publications List

Publications List

Publications List

Publications List

National, Regional and State Association News

Listing of Regional and State Political Science Associations

National Political Science Association

Research Support

1994 Research Support Grants Announced

Women and Minorities

Ralph Bunche Program Suspended for Summer

Association Establishes Graduate Fellowship Program for Native American Students

Participation by Women in the 1994 APSA Meeting

Women's Caucus for Political Science Celebrates Its 25th Year

Atlanta Ralph Bunche Summer Institute Consortium Honored

APSA Minority Fellows Selected

June 1995

September $1994 \quad 587$

September $1994 \quad 634$

December $1994 \quad 769$

March 1995

September $1994 \quad 658$

December $1994 \quad 826$

March $1995 \quad 178$

June $1995 \quad 291$

March $1995 \quad 140$

June $1995 \quad 269$

September $1994 \quad 595$

September $1994 \quad 590$

September $1994 \quad 592$

December $1994 \quad 741$

December $1994 \quad 742$

December $1994 \quad 747$

June 1995264

\title{
The American Political Science Review Book Review, 1991-95
}

\author{
Melissa P. Collie, ${ }^{1}$ University of Texas at Austin
}

This report discusses the operation of the American Political Science Review Book Review during my editorship, 1991-94. In this period the Book Review received more than 6,000 books for consideration. Of these, 940 were selected and reviewed in the September 1992March 1995 issues of the APSR. The Book Review also commissioned review essays on major topics in political science that were written by distinguished scholars including Herbert Kitchelt, regime transformation; David Brady, divided government; Leslie Greene, natural law; James Stimson, public opinion and representation; Jean Elshtain, feminist theory; Elinor Ostrom, the significance of political institutions; David Laitin, political culture; and Allen Buchanan, communitarianism and liberalism.

Two tasks are the most important to the operation of the Book Review: selection of books and of reviewers. This report describes operation of the Book Review in terms of these tasks. A final section considers the interdependence between book and reviewer selection and the way this interdependence affects the quality of individual reviews and that of the Book Review as a whole.

\section{Selecting Books}

To elaborate on the numbers cited and illustrate the current scope of the Book Review, Table 1 
The American Political Science Association's

\section{Evron M. Kirkpatrick Fund \\ to foster growth and development of political science \\ as a discipline and profession}

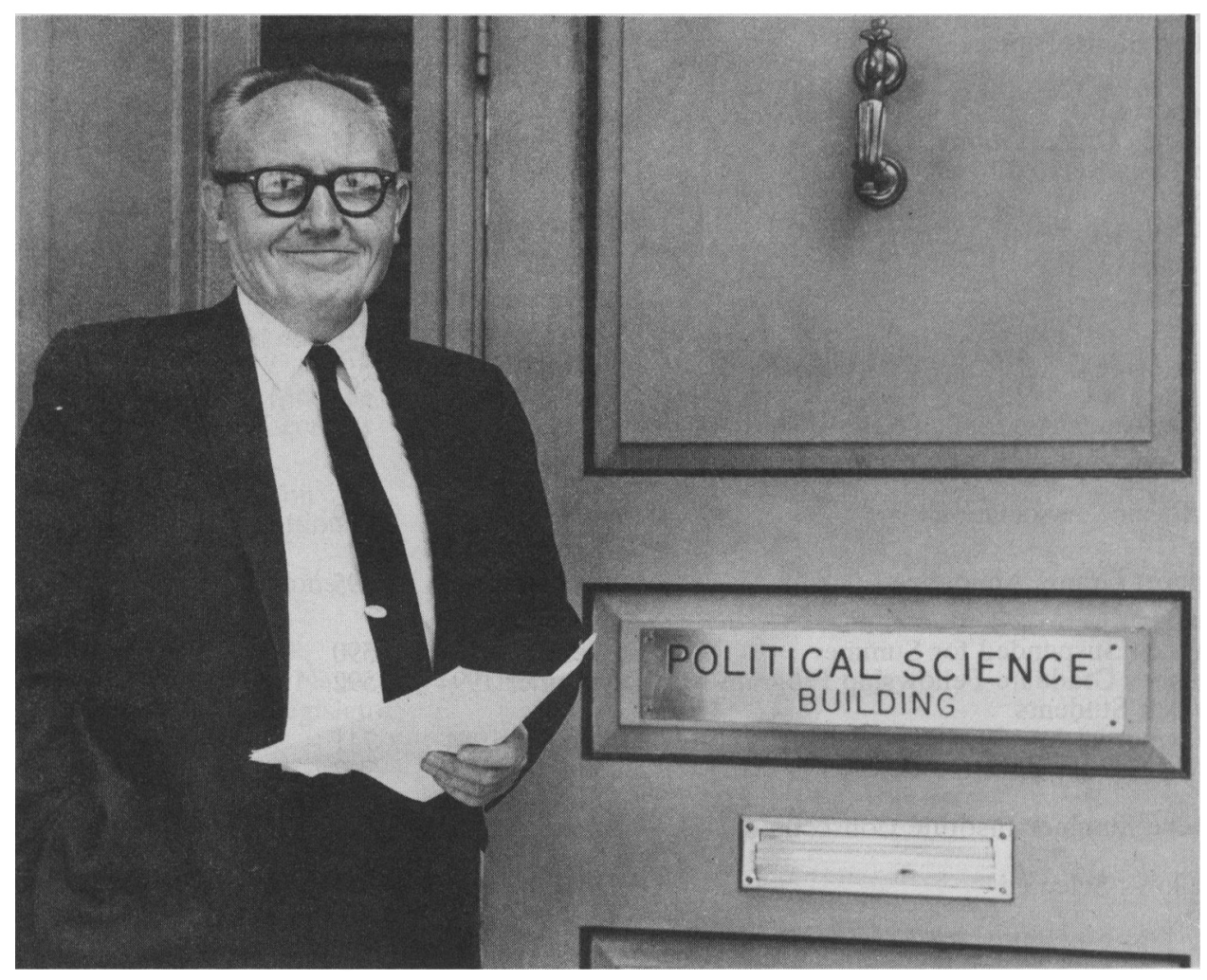

Evron M. Kirkpatrick, 1912-1995

The Kirkpatrick Fund was established by the APSA Council in 1982 to honor Evron M. Kirkpatrick's 27 years of distinguished service as APSA's second executive director. It is, therefore, fitting that the Trustees of the Kirkpatrick Fund invite members of the Association to contribute to the Evron M. Kirkpatrick Fund. Contributions are tax deductible.

Contributions in the form of a check should be made out to: APSA KIRKPATRICK FUND, and sent to the Association's national headquarters:

1527 New Hampshire Avenue, NW

Washington, DC 20036 


\section{TABLE 1}

Books Received and Reviewed or Scheduled for Review in the APSR Book Review, Summer 1991-August 1994

\begin{tabular}{|c|c|c|c|c|c|c|}
\hline \multirow[b]{2}{*}{ Field } & \multicolumn{2}{|c|}{$\begin{array}{c}\text { Summer 1991-July } \\
1992\end{array}$} & \multicolumn{2}{|c|}{$\begin{array}{c}\text { August } 1992-\text { July } \\
1993\end{array}$} & \multicolumn{2}{|c|}{$\begin{array}{l}\text { August } 1993 \text {-August } \\
1994 \\
\end{array}$} \\
\hline & $\begin{array}{c}\text { Received } \\
\mathrm{N}\end{array}$ & $\begin{array}{c}\text { Reviewed } \\
\%(\mathrm{~N}) \\
\end{array}$ & $\begin{array}{c}\text { Received } \\
\mathrm{N}\end{array}$ & $\begin{array}{c}\text { Reviewed } \\
\%(\mathrm{~N})\end{array}$ & $\begin{array}{c}\text { Received } \\
\mathbf{N}\end{array}$ & $\begin{array}{c}\text { Reviewed } \\
\%(\mathrm{~N}) \\
\end{array}$ \\
\hline $\begin{array}{l}\text { Political Theory } \\
\text { American Politics } \\
\text { Comparative Politics } \\
\text { International Relations }\end{array}$ & $\begin{array}{l}642 \\
281\end{array}$ & $\begin{array}{l}29.6(162) \\
21.8(140) \\
29.9(84)\end{array}$ & $\begin{array}{l}686 \\
343\end{array}$ & & $\begin{array}{l}840 \\
483\end{array}$ & $\begin{array}{l}20.0(69) \\
14.2(97) \\
13.6(114) \\
17.4(84)\end{array}$ \\
\hline Totals & 1743 & $26.9(468)$ & 1982 & $28.2(559)$ & 2353 & $15.5(364)$ \\
\hline
\end{tabular}

Note: The N under "Received" is the total number of books received by the APSR Book Review office for that period. The N under "Reviewed" is the number of books for which invitations were issued. presents the number of books received and the percentage for which invitations to review were issued in 1991-94. As the table shows, the total number of books sent by publishers for possible review increased each year, from 1,743 to 2,353 , as did the number in each of the four fields. The Book Review consistently received more books in the field of comparative politics, and, in descending order, American politics, international relations: and political theory. The percentage of books for which we issued invitations to review varied from a high of $28.2(1992-93)$ to a low of 15.5 (1993-94).

In selecting books for review, I focused on new scholarship that was theoretical in orientation and contributed to important research questions in the relevant field of political science. A notable but rare exception to this standard for selection was the book organized to present a political scientist's cumulative body of work, thus allowing a review of the intellectual development and wider implications of a single political scientist's research. Examples included books on selected works of Harry Eckstein and Martin Diamond.

Political scientists wrote most books for which reviews were commissioned. Still, the subject matter of political science often intersects that of other disciplines, including anthropology, philosophy, sociology, history, economics, law, and psychology. When an important book by a non-political scientist directly engaged the literature in political science, it was considered for review.

Table 2 presents a breakdown of the books reviewed by field in 1991-95. For the most part, there is a fairly even distribution of books among the fields. Exceptions include the light coverage of comparative politics in the September 1993 issue, its heavy coverage in the June 1993 issue, and the heavy coverage of American politics in the September 1992 issue.

The distribution in Table 2 reflects primarily the fact that the Book Review is supply-driven, in both books and reviews. From 150 to 200 publishers send books for consideration each year. Still, no matter how slim the selection at a given time for a particular field, the Book Review has no ability to generate additional scholarship. And, although recalcitrant reviewers may be decommissioned, a lag is necessarily built into the review process because of the publication schedule and the necessity of providing reviewers with a reasonable amount of time to assess books. Rather than artifically induce distributional equality among the fields in each issue, reviews were sent to press as they arrived, a routine reviewers and authors usually consider optimal.

\section{Selecting Reviewers}

The selection of reviewers is as important as the selection of books. It is also especially delicate from the perspective of both reviewers and authors, because (as opposed to the referee process associated with manuscripts) reviewers' reactions become public. Reviewer selection is a multistep process and occupies a major part of the editor's time as well as that of the staff.

In selecting reviewers, I targeted scholars whose research had recently contributed to the particular area of scholarship addressed in the book. With this criterion as the primary factor behind selection, a list of four to five possible reviewers

\section{TABLE 2}

Books Reviewed in the September 1991-March 1995 APSR Book Review

\begin{tabular}{lccccr}
\hline & $\begin{array}{c}\text { Theory } \\
\%(\mathrm{~N})\end{array}$ & $\begin{array}{c}\text { American } \\
\%(\mathrm{~N})\end{array}$ & $\begin{array}{c}\text { Comp } \\
\%(\mathrm{~N})\end{array}$ & $\begin{array}{c}\text { IR } \\
\%(\mathrm{~N})\end{array}$ & $\begin{array}{r}\text { Total } \\
\text { N }\end{array}$ \\
\hline September 1991 & $24.8(25)$ & $32.7(33)$ & $24.8(25)$ & $17.8(18)$ & 101 \\
December 1991 & $23.5(19)$ & $25.9(21)$ & $34.6(28)$ & $16.0(13)$ & 81 \\
March 1992 & $24.0(35)$ & $34.9(51)$ & $24.0(35)$ & $17.1(25)$ & 146 \\
June 1992 & $18.6(26)$ & $31.4(44)$ & $27.9(39)$ & $22.1(31)$ & 140 \\
September 1992 & $13.6(11)$ & $44.4(36)$ & $24.7(20)$ & $17.3(14)$ & 81 \\
December 1992 & $20.8(21)$ & $25.7(26)$ & $36.6(37)$ & $16.8(17)$ & 101 \\
March 1993 & $14.7(14)$ & $38.9(37)$ & $31.6(30)$ & $14.7(14)$ & 95 \\
June 1993 & $18.8(18)$ & $22.9(22)$ & $49.0(47)$ & $9.4(9)$ & 96 \\
September 1993 & $30.3(27)$ & $29.2(26)$ & $12.4(11)$ & $28.1(25)$ & 89 \\
December 1993 & $21.4(15)$ & $34.3(24)$ & $21.4(15)$ & $22.9(16)$ & 70 \\
March 1994 & $26.8(15)$ & $21.4(12)$ & $26.8(15)$ & $25.0(14)$ & 56 \\
June 1994 & $24.4(22)$ & $31.1(28)$ & $23.3(21)$ & $21.1(19)$ & 90 \\
September 1994 & $26.3(21)$ & $33.8(27)$ & $18.8(15)$ & $21.3(17)$ & 80 \\
December 1994 & $23.3(20)$ & $32.6(28)$ & $26.7(23)$ & $17.4(15)$ & 86 \\
March 1995 & $6.3(6)$ & $29.2(28)$ & $34.4(33)$ & $30.2(29)$ & 96 \\
\hline
\end{tabular}

Ns include books reviewed in review essays and multiple- and single-book reviews.

Reviews appearing in September 1991 through June 1992 APSR issues were commissioned by the Book Review Office at the University of Arizona. Ns include books reviewed in review essays and multiple- and single-book reviews. 
was compiled. The possible reviewers were drawn from a variety of sources, including an extensive data bank on reviewers maintained by the APSR Book Review, authors' references, annual conference participants, and on-line information regarding books and articles published. As an aid in the selection process, the list of possible reviewers contained, as to each candidate, a limited profile of recent scholarship, university affiliation, and professional status.

While recent research contribution was the main determinant behind reviewer selection, selection was also peer-sensitive, which is to say that when possible the author's professional status approximated the reviewer's. This policy meant that graduate students were not asked to review books during my editorship. Although some individuals found this consequence troubling, it reflected my more general emphasis on determining the intellectual track records of potential reviewers before requesting reviews from them.

To maintain the integrity of the review process, we adopted a number of rules that further restricted the choice of reviewers. Individuals upon whom the author had personally relied, as reported in the acknowledgments, were excluded from consideration as were previous coauthors and all members of university departments with which contributors to the book were affiliated. Although we actively solicited and retained information about individuals who wished to review in certain areas, we did not honor requests to review specific books.

The average number of reviewers who were invited to review a book was two. Table 3 presents a breakdown by issue of the percentage of books that were reviewed by the scholar invited first, second, and so on. This table shows that between 40 and $50 \%$ of books in most of the issues were reviewed by the first individual invited to review. Another considerable proportion, usually between 20 and $30 \%$, was reviewed by the second reviewer contacted.

More times than not, several good choices present themselves,

\begin{tabular}{|c|c|c|c|c|}
\hline \multirow[b]{2}{*}{ Issue Date } & \multicolumn{4}{|c|}{ Reviewer Invitations Per Book } \\
\hline & $\begin{array}{c}1 \\
(\mathrm{~N}) \\
\end{array}$ & $\% \stackrel{2}{(\mathrm{~N})}$ & $\stackrel{3}{(N)}^{2}$ & $\begin{array}{c}\geq 4 \\
\%(\mathrm{~N}) \\
\end{array}$ \\
\hline September 1992 & $69.1(56)$ & $19.8(16)$ & $11.1(9)$ & $0.0(0)$ \\
\hline December 1992 & $56.4(57)$ & $20.8(21)$ & $13.9(14)$ & $8.9(9)$ \\
\hline March 1993 & $50.5(48)$ & $27.4(26)$ & $13.7(13)$ & $8.4(8)$ \\
\hline June 1993 & $50.0(48)$ & $24.0(23)$ & $12.5(12)$ & $13.5(13)$ \\
\hline September 1993 & $33.7(30)$ & $25.8(23)$ & $20.2(18)$ & $20.2(18)$ \\
\hline December 1993 & $41.4(29)$ & $25.7(18)$ & $17.1(12)$ & $15.7(11)$ \\
\hline March 1994 & $37.5(21)$ & $28.6(16)$ & $12.5(7)$ & $21.4(12)$ \\
\hline June 1994 & $41.1(37)$ & $27.8(25)$ & $11.1(10)$ & $20.0(18)$ \\
\hline September 1994 & $40.0(32)$ & $32.5(26)$ & $10.0(8)$ & $17.5(14)$ \\
\hline December 1994 & $46.5(40)$ & $22.1(19)$ & $12.8(11)$ & $18.6(16)$ \\
\hline March 1995 & $43.8(42)$ & $22.9(22)$ & $12.5(12)$ & $20.8(20)$ \\
\hline
\end{tabular}

which means that distinctions among the first, second, and even third reviewers often are not consequential for the expected quality of the review. Nonetheless, these percentages are all the more impressive when the quality of the reviewers targeted-that is, scholars making recent contributions to the book's substantive area-is taken into account.

\section{Interdependencies}

The chief objective of the Book Review is to provide authoritative reviews of important scholarship in political science. In meeting this objective, the Book Review addresses multiple constituenciesauthors, reviewers, publishers, readers-whose expectations of it overlap one another but are not identical. Partly because of this objective, partly because of the different constituencies' expectations, and partly because of the sheer volume of books published in political science, book and reviewer selection occurs within a context of competing demands to enlarge the number of works that are reviewed and to enhance the quality of the reviews themselves.

With space finite, there is inevitably a tradeoff between these competing demands. Reviewing more books means having shorter reviews, which usually results in lesser, not merely pithier, assessments. Enhancing the quality of reviews means engaging quality reviewers, which is not merely a matter of identification but also of recruitment. Here space comes into play more subtly. If the Book Review is to recruit reviewers of high quality, it must provide them both with books of substance and significance and, equally important, with the opportunity to evaluate them. The former can and should be debated; the need for such debate motivates the review process. The latter means space.

There is, then, an interdependence between book and reviewer selection that is based on more than a match between the subject matter of books and the expertise of reviewers. That is, better books attract better reviewers. Still, the quality of individual reviews does not result only from the connection of the right reviewer with the right book. It is also contingent on the production of a thoughtful and thorough review. For this effect, I have assumed that space is a necessary but not sufficient condition.

Resolving these competing demands involves judgment about the use of existing space. During my editorship, I erred in the direction of assigning reviewers more space than was available to them in the past. The decision raised the word allotment for single-book reviews $66 \%$, for two-book reviews $75 \%$, and for review essays to a range that was 80 to $140 \%$ greater than the previous allotment. As implied earlier, this change was intended to 
increase the potential for reviewers to adopt a reflective and analytic posture toward each book's contribution to scholarship. Its greatest effect probably was on the nature of the review essays, where essayists were encouraged to use the set of books selected for the essay as a platform to examine critically the theoretical and methodological issues regarding the specific research questions addressed in the books.

My impression is that expanded review length resulted in better reviews. The alternative-writing less about more-still seems somewhat misguided, if for no other reason than the poor use it makes of scholars' talents. I also believe that the contribution and quality of the Book Review as a whole is fundamentally based on the quality and contribution of the individual reviews. In the best of circumstances, the Book Review becomes not only a format for disseminating information about the existence of current scholarship but also a format for contemplating it in depth.

\section{Notes}

I first wish to thank Bing Powell for the opportunity to work as Book Review Editor and for his support during my editorship. The Book Review Office could not have functioned as smoothly as it did without the help of the graduate students who staffed it and assisted in every minor and major decision made. Nor would my experience as an editor have been nearly as pleasurable as it was. I thank Tim Fackler, Nathalie Frensley, Rodd Freitag, John Janssen, and Chris Marshall for their invaluable contributions. I especially thank Tim Fackler for assistance in preparing this report.

\section{Report on the Status of Lesbians and Gays in the Political Science Profession}

\section{Prepared by Committee on the Status of Lesbians and Gays in the Profession of the American Political Science Association ${ }^{1}$}

\section{Introduction}

Gay, lesbian, and bisexual visibility is such a recent phenomenon, and sexual diversity so little understood in the population at large, that the status of sexual minorities in the political science profession is difficult to decipher. ${ }^{2}$ While a number of other professional organizations established "status committees," and began research on these issues as early as the $1970 \mathrm{~s}$, the beginnings of a gay and lesbian caucus in political science attracted only modest numbers as recently as a decade ago, with most members wary of identifying their sexual orientation in a professional context. The mere idea of surveys such as those conducted by the APSA in September 1993 would have been unthinkable.

The APSA Council's establishment of the Committee on the Status of Lesbians and Gays in 1992 is one significant sign of change. ${ }^{3}$ So, too, is the growth of the Gay, Lesbian, Bisexual Political Science Caucus to a membership of 161 people, and its sponsorship (or cosponsorship) of 10 panels on gaylesbian related themes at the 1995 Annual Meeting.

Nevertheless, this history tells us little about the actual status of gays and lesbians in the professioneither as gays, lesbians, and bisexuals themselves view it, or as perceived by their heterosexual colleagues. The surveys of department chairs and of individual APSA members' opinions flag other signs of professional and institutional change in response to the challenge to create a more inclusive climate for sexual minorities. They also provide indications of how much remains to be done. These surveys reveal what political scientists would expect, that opinions vary greatly among both gays/lesbians/bisexuals and heterosexuals about the extent of inclusion and about appropriate responses. Perceptions among the latter are particularly varied, and any reading of their responses is inevitably confounded by the desire of most to avoid the subject altogether.

Any analysis of the 1993 surveys must begin, then, with an acknowledgment that they give us only fragmentary and prismatic glimpses of the status of gays and lesbians in the profession. Those individual Association members who took the questionnaire seriously enough to fill it in are obviously an unrepre- sentatively self-selective subset of Annual Meeting attenders or of the APSA more generally. ${ }^{4}$ That is true of the lesbian and gay members, and even more true of those who identify as heterosexual. The responses of all are reflective of their own particular perceptions of realities, no doubt filtered substantially by the perspectives they bring to all their observations.

The responses of department chairs must also be approached with caution. Many department chairs have had virtually no experience in thinking about sexual diversity issues. Those who did reply may well be those who had the strongest feelings (whether positive or negative). In addition, chairs could be expected to filter their perceptions on the basis of what they believe lies in the best interests of their departments.

All that said, how do we evaluate the status of gays, lesbians, and bisexuals in the profession of political science? In this report we explore a number of the measures addressed in the surveys. One indicator is the degree of visibility or "outness" of gays and lesbians in the profession, because achieving visibility is a crucial way to chal- 